\title{
Toxic Leadership and Organisational Silence: An Appraisal of Selected Faith-Based Organisations in Ogun State, Nigeria
}

\author{
Solomon O. Adeoye ${ }^{1 *}(\mathrm{PhD}) \quad$ Olive U. Egbuta ${ }^{2}(\mathrm{PhD}) \quad$ David Ayeni $^{3}$ \\ Department of Business Administration and Marketing, School of Management Sciences, \\ Babcock University, Ilisan-Remo, Ogun State, Nigeria \\ P.M.B. 21244, Ikeja, Lagos, Nigeria
}

\begin{abstract}
This study examined the effect of toxic leadership on organisational silence in selected faith-based organisations in Ogun State, Nigeria. It debates that securing endurable paths to organisation success requires keen attention to the menace of organisational silence, and this does not leave out organisations that base their business operations on certain fundamental doctrines, corporate practices, or religious believes. Survey research design was adopted. The population of the study was seven hundred and seventy-five (775) staff drawn from the selected faith-based organisations in Ogun State, Nigeria. The study adopted multi-stage sampling technique. Structured questionnaire was adapted, validated and used for data collection. Cronbach's Alpha Reliability Analysis ranged 0.704 to 0.775 . Descriptive and inferential statistics were used for data analysis. Findings revealed that Toxic leadership had significant effect on Organisational silence (Adj. $\left.R^{2}=0.475 ; F(4,361)=83.60, p<0.05\right)$. This revealed that organisational silence exists as a result of toxic leadership, and to this end, employers and managers are expected to take every affordable step to weaken the weight of organisational silence by deploying quality leadership that encourages cross fertilization of ideas, creativity, ingenuousness and knowledge extension among employers, managers and employees.
\end{abstract}

Keywords: Toxic leadership, Organisational silence, Corporate practices, Organisational communication, Ogun State, Nigeria.

DOI: $10.7176 / \mathrm{JRDM} / 67-05$

Publication date:July $31^{\text {st }} 2020$

\section{Introduction}

Securing endurable paths to organisation success requires thoughtful attention to the menace of organisational silence in the workplace. This does not leave out likewise organisations that base their business operations or corporate practices on certain fundamental doctrines or religious believes.

The force of toxicity in many workplaces is repeatedly manifesting through repressive leadership and hostile work environment, of which, majority of workers are being compelled to adapt to agreeable personality of silence that is extraordinary in nature (Spranger, 2008). The challenge is obscurely dominant in most organisations as workers hesitate to offer tangible imputes that can provide solution to organisation problems. Situational challenges are ignored while lack of team spirit creeps into critical matters that border on the progress of the organisation (Akinyele, 2010). The consequence of this therefore is scarcity of useful ideas for leadership to operate with, and hindrance to organisations' ability to invent and innovate corporate strategies (Adeoye, 2017; Houseman \& Minor, 2015).

According to the 2017 annual report of the World Economic Forum (WEF) released by the United Nation Development Programme, Nigeria (UNDP), eighty per cent $(80 \%)$ of workers ignore contribution towards developmental matters in the workplace due to fear of criticism and victimisation. Thus, the statistic of workers' indisposition to issues confronting organisations in Africa is alarming because workers perceive their work environment as unsafe for exploration and adventure (Malikeh \& Zohre, 2012, UNDP, 2017). Study conducted in South Africa depicts forty-three per cent (43\%) of non-expression of opinions among workers on issues that bother on organisational progress (Elci, Eridilek, Alpkan \& Sener, 2014). However, available studies on employees behavior, organisational cost, personnel economics, wellbeing and employee productivity, do less or no exploit regarding the effect of toxic leadership on organisational silence (Akinyele, 2010; Ermongkonchai, 2010; Oberholzer-Gee \& Wulf; 2012), hence, VanHoof, Xu, Serrano and Torres (2015), and Mehta, Maheshwari and Sharma (2014) acknowledged the need to fill the gap.

The decision of workers on whether or not to keep silent to matters within organisation depend on the prevailing circumstances surrounding issues such as resources distribution, leadership decision making style, and interaction processes among organisation members (Rastgar \& Pourebralimi, 2013). It is in this context that Karatepe and Shahriari (2012), Kumar (2014) and Sarnecki (2015), agreed that the inability of organisation to attain fairness in resource allocation hinders harmonious working relationship among employees.

Meanwhile, Housman and Minor (2015) focused on the potential advantages in the employment of a toxic personality in the workplace. Their study found positive relationship between toxic individual and organisational performance. Housman and Minor (2015) affirmed that even though a toxic worker is difficult, the work 
performance is outstanding because such worker thrives in productivity. This is supported by scientific management theory of Taylor (1974). Taylor criticised workplace flexibility by owning to the opinion that not all organisational leadership behaviours invoke a toxic environment of fear and anxiety, but majority of workers are not matured in the ways of work. Taylor submitted that many workers possess self-centred aspirations and timehorizons different from that of the organisation. Therefore, as long as personal plans negate the objectives and time-horizons of organisations, there is tendency that personal objectives prevail over organisational objectives. Hence the theory argued that except organisation applies certain measures through rigid control of workplace activities; it cannot produce optimally, thereby supporting the act of toxic leadership.

Consequently, in today's work environment, including business and service oriented environment where unemployment is predominant, employees deem it fit to tolerate leadership by act of silence rather than embark on turnover. This act is related to what Schwalbe, Godwin, Holden, Schrock, Tompson and Wolkomir (2000) referred to as Subordinate Adaptation Theory (SAT) as affirmed in Adeoye (2017). Rather than workers being subdued by the harmful effect of toxic leadership, the theory elucidates the attribute of employees' silence within organisation in the following ways: that the affected workers could fit into a dominant group within the workplace for some kinds of benefits in order to exchange power for patronage, form associations with workers of similar experience in an attempt to create alternative spaces of power and prestige, accept inferior position and try to make the environment tolerable, or create a niche to exploit and undermine the system.

In several related empirical studies, Pierce and Snyder (2008) carried out investigation on the impact of workplace environment on workforce and submitted that workplace environment is positively significant to employees' productivity. This assertion was opposed by Gino and Ariely (2012) and Frank and Obloj (2014), while maintaining that toxic work environment is less significant on productivity. In a similar context, Deter and Burris (2007) corroboratively examined three managerial factors affecting power of expression (voicing). The author found that change orientation, work involvement and access to organisation resource are related to voicing. Pichora-Fuller, Kramer and Wingfield (2016) as well identified with Deter and Burris (2007) in that, voice behaviour is related to employees' change orientation. Deter and Burris's finding is grounded on the point that a change or a reaction occurred when employee is side-lined or hindered to participate in decision making on issues that pertain to organisation. This changed-psychological tension (Deter \& Burris, 2007) is what Tas, Bos-Semerci and Ergeneli (2017) in a similar background examined as effect of silence on emotional burnout, frustration and fatigue. It was indicated that silence is positively related to emotional burnout, frustration and fatigue. Altuntas (2010), and Qureshi, Iftikhar, Janjua, \& Zaman (2015) in a similar study discovered silence as being related to psychological tension. In other words, the findings of Tas et al. (2017) is similar to the earlier discovery of Altuntas (2010). It is based on these allusions that the researcher hypothesized that Toxic Leadership has no significant effect on organisational silence.

\section{Workplace Toxicity}

Kussy and Holloway (2009) defined workplace toxicity as any appearance of pollutant capable of causing counterproductivity in the workplace. This expression is similar to the description by Lipmon-Blumen (2016) who defined toxic leadership as an exposure of organisation and workers to pervasive and oppressive work environment. Gilbert, Car-Ruffino, Ivancevich and Konopaske (2012), however, described workplace toxicity as a circumstance of middling performance being compensated above merit-based output, a feature of an intent of leadership subduing subordinate to servitude (Gilbert, et al. 2012). Whereas, Gino and Ariely (2012) and Frank and Obloj (2014) stated the possible benefit in the employment and appointment of a toxic leader, in the sense that, a toxic leader thrives in work performance and enjoys friendship with management and stakeholders of the organisation served. This is corroborated by Housman and Minor (2015) who described a toxic leader as someone with anti-social personality but with outstanding performance. This explained why organisation retains a toxic leader for a long time. Besides, Frank and Obloj (2014) suggested to organisation to either choose increased productivity and amplify inclinations for toxicity, or lower productivity to avoid or reduce workplace toxicity. In other words, for a toxic manager or leader to perform optimally, justice and ethical practices have to be partially set aside.

Conversely, the disadvantage of toxic leadership, according to Gilbert et al. (2012) is that, it costs organisation time and resources in resolving issues such as overtime cost, turnover cost, potential legal costs, and anger management and training cost, including administration of salary and benefits. Gilbert et al. (2012) assertion is similar to Housman and Minor (2015) who expose the disadvantages of workplace toxicity to organisation in connection with the three signature behaviours of a toxic leader namely: shaming, passive hostility and team sabotage. The earlier reaction of Kussy and Holloway (2009) explained toxic leadership as hindrance to useful ideas and perspectives that could have offered adequate support to organisational development.

Zimbardo (2004) explained further certain factors that can lead to a toxic workplace as follows: lack of employee behavioural census, excessive demand from superiors, unrealistic work ultimatum and time schedules, and over focus on self-advancement. In such environments, employees are over-burdened with work, strapped with tight deadlines, and do not maintain and enjoy work-life balance, while the Managers are on themselves 
preoccupied with own status and power (Hymowitz, 2007). Toxic behaviour therefore is adjudged as being selfcentred and insensitive to the needs of others (Zimbardo, 2004).

To attain the highest level of achievement within organisation, Kussy and Holloway (2009) has highlighted three ways of preventing toxicity as follows: organisational value, team communication and individual evaluation. Kussy and Holloway (2009) upheld that organisation must have well-defined behavioural specific core-values in writing, and should be observed. These core-values visibly recognize the types of behaviours that the organisation should accept and those that are not acceptable. They are stated in precise and clear terms with very rare chances for misconception. The core-values incorporate strong penalties once employees violate them. The management adheres to the standard by modelling values by example themselves. At the team level however, all round team communication and response (360-degree team feedback) including individual interview are required to help measure team dynamic forces. Exit interview is needed to unearth the intention for turnover, recognize and do the work needed to repair the team and restore trust and healthy relationships after the toxic person has left (Kaye \& Jordan, 2014). The individual evaluation however includes targeted corrective feedback, performance reviews/appraisals, coaching, and termination of a toxic worker (Kussy \& Holloway 2009).

With reference to the above, workplace toxicity can be defined as exposure of workplace and workforce to persistent tyrannical condition capable of debilitating the physical and psychological condition of employees and the progress of the organisation. In a toxic environment, the impact of toxicity is felt by every member of the organisation be it employer, manager or employees.

\section{Organisational Silence}

Malikeh, Hossein and Mahmood (2012) observed that when majority of employees in an organisation decide to be quiet in any matter pertaining to organisation, silence becomes a collective behaviour, and this is being referred to as organisational silence. Organisational silence assumes different dimensions, but the prime is deliberate reticence of employees when matters that are sensitive to organisational growth are being discussed (Huang, Van, \& Evert, 2005). Silence of employees in the workplace is connected to several qualities such as modesty, respect for others, carefulness and dignity. Meanwhile, employees also keep quiet to avoid victimization, embarrassment, confrontation and other apparent workplace tussle (Perlow \& Williams, 2003).

In a related context, organisational silence is defined as lack of organisational communication (Van, Ang \& Botero, 2008). Acaray and Akturan (2015) simplified the concept as employees' speechlessness. To Elci et al. (2014), organisation silence creates uncomfortable work climate for employees, the management and organisation as a whole. This is because, when an organisation is experiencing silence, employees exhibit silent behaviours even in critical times and circumstances to the detriment of the organisation. Organisational silence therefore conveys consent, involvement, disfavour and opposition, thus becoming a burdensome tool to effective performance and organisational growth (Bagheri, Zarel \& Aeen, 2012, Erdrencelebi \& Sendogdu, 2016).

Morrison (2014) noted the advantages of Organisational communication as it helps employers and management to harvest suggestions, concerns, information and challenges confronting organisation. In the light of this, Morrison and Milliken (2017) described Organisational silence as a dangerous behaviour that is capable of impeding organisational growth, performance and development. It is for this reason that Vokola (2014) explained organisational silence as a range between two factors-"silence and voice", in that, when voice is being withdrawn from the workplace, organisation is then being deprived of salient pieces of information that can accelerate its growth. Ellis and Dyne (2009) therefore suggested that organisational silence be given adequate attention in order to reduce its damaging impact in the workplace. Whereas, Karaca (2013) classified organisational silence into three different characteristics: first, silence can be deliberate, that is, employees may refuse to speak out despite the awareness of problems and the knowledge of better solution. Second, silence can be used as a defence mechanism to safeguard personal interests or to avoid disagreement with others. Lastly, silence can be a resolute action by employee to prevent sharing of ideas, thoughts, or knowledge with others. Karaca (2013) re-affirmed that keeping silent in the workplace not only undermines knowledge sharing, but also impedes collective brainstorming, problem identification, and possible solutions to workplace-related issues.

Malikeh, Hossein and Mahmood (2012) highlighted the following as causes of silence: fear, embarrassment, narrow concept, ethical responsibility, lack of opportunity for "voicing" (platform for expression) and lack of organisational political skills. Malikeh, et al (2012) believed that most employees are afraid of conflict and assume that any opposition against 'powerful people' may result to heavy retribution against the opposition. Facts have been established that whistle blowers are being hit back in their organisation, private and family lives. Therefore, many employees are unwilling to discuss any subject that pertains to their organisation be it money, politics, humanity, sport or ethics because they think that they may not be able to properly or technically explain their views. Employees rather own to the view that once a person understands what is ethical and do not behave unethically; the person remains morally decent, even, when unethical behaviour triumphs around such person. Richard (2003) corroboratively maintained that employees are not indebted to mere seeing, hearing, speaking but also nonspeaking about unethical behaviours within organisation. 
Van, Ang and Botero (2003) underlined three precise types of silence based on employee motives: acquiescent silence, defensive silence, and pro-social silence. Acquiescent silence has to do with concealment of pertinent ideas, information, or opinions, based on attitudes that are more passive than active. Defensive silence is a deliberate attitude that is planned to protect one-self from external threats. Different from acquiescent silence, defensive silence is more pre-emptive, containing consciousness and attention to choices, followed by a conscious decision to withhold ideas, information, and opinions as the best individual scheme at that present time. Pro-social silence, however, is an act of withholding work-related ideas, information, or opinions that are beneficial to employees or the organisation based on humanity or cooperative motives. Pro-social silence is intentional and proactive behaviour that is primarily focused on others.

Meanwhile, Ozdemir and Sarioglu-Ugur (2013) drew attention to the effect of organisational silence in that, in an organisational-silent environment, innovative ideas are scarce and that gives leeway to autocracy. For this reason, organisation find it difficult to solve its problems (Souba, Way, Lucey, Sedmak, Notestine, 2011). Cetain, Karabay, Ozcan \& Taskeran (2013), and Kilic, Tunc, Saracli, Kilic (2013) further projects that Organisational silence is capable of leading to lack of employees' satisfaction and degradation of general functions of the enterprise Bagheri et al. (2012) affirmed that unresponsive employees cause organisations to function poorly and consequently lose money and diminish profitability. Regrettably, the detected loss causes the managers negative reactions while trying to recover the loss orchestrated by employees due to some unresolved issues. Thus Organisational-silence can become a venomous circle.

In congruent with the position of the authors discussed above, Organisational silence can be defined as a deliberate intention of employees to remain indifferent, due to unsettled workplace relational matters, to certain ideology that could have stimulated the growth of organisation. In other words, employees' deliberate act of withholding ideas, knowledge or opinions capable of improving organisational performance is hereby described as Organisational silence.

\section{Methodology}

The study adopted survey research design due to its suitability for quantitative appraisal of lager population. It was designed for data collection and analysis on Toxic Leadership and Organisational silence. Hollis (2015) investigated similar studies using survey research design and quantitative method of data analysis. The design is beneficial in terms of cost, extension, flexibility and dependability (Defranzo, 2012), and it can be administered through different means. Its confidentiality allows respondent to respond to questions without prejudice (Adeoye, 2017). Target population was Seven Hundred and Seventy-five (775) low and middle level management staff of two (2) selected faith-based organisations in Ogun State, Nigeria, representing eighty per cent of the total population distribution of the staff of the organisations. The criteria for adopting eighty per cent ratio was based on the prescription of the Administration and Management services of the selected organisations, where eighty per cent of the administrative staff fell within the lower and middle level categories. The decision to adopt faith-based organisation as the research context, however, was due to its unique composition and characteristics different from inter-governmental Local, State and Federal organisations in relation to ownership, structure, control and funding. Respondents cut across different functional areas and department of the selected organisations; including registry workers, accountants, health workers, human resources officers, maintenance officers, facility engineers, ground officers and supervisors, food services employees, nutritionists and chefs. The minimum educational qualification is National Diploma (ND) Certificate or National Certificate of Education (NCE) and maximum of Doctor of Philosophy (PhD).

The sampling frame comprised of the distribution from the lower to the middle level across the two (2) selected organisations. However, the distribution was done based on ratio 33:67 at the Lower level management versus Middle level management respectively. This becomes necessary because a larger population of staff members lie within these management categories.

Table 1. Selected faith-based Organisations

\begin{tabular}{|l|l|l|l|l|l|l|}
\hline $\begin{array}{l}\text { Sample } \\
\text { Size }\end{array}$ & $\begin{array}{l}\text { Selected faith- } \\
\text { based } \\
\text { Organisation }\end{array}$ & $\begin{array}{l}\text { General Staff } \\
\text { Population }\end{array}$ & $\begin{array}{l}\text { Target } \\
\text { Population } \\
\text { (Bottom-Middle) }\end{array}$ & $\begin{array}{l}\text { Total No of } \\
\text { respondents } \\
\text { (Sample Size) }\end{array}$ & $\begin{array}{l}\text { Lower } \\
\text { Level }\end{array}$ & $\begin{array}{l}\text { Middle } \\
\text { Level }\end{array}$ \\
\hline N=338 & & $\mathbf{1 0 0 \%}$ & $\mathbf{8 0 \%}$ & & $67 \%$ & $\mathbf{3 3 \%}$ \\
\hline & B & 519 & 415 & 181 & 121 & 60 \\
\hline & C & 450 & 360 & 157 & 105 & 52 \\
\hline TOTAL & $\mathbf{9 6 9}$ & $\mathbf{7 7 5}$ & $\mathbf{3 3 8}$ & $\mathbf{2 2 6}$ & $\mathbf{1 1 2}$ \\
\hline
\end{tabular}

\section{Source: Field Survey}

The statistical formula by Krejcie and Morgan (1970) was adopted in calculating the sample size having been justified based on accurate measure and easy reference offered by the formula. It is fit for defining sample size of a finite population as being estimated at 5.0 margin error of $95 \%$ confidence level. The population of the selected 
organisations fell within the range of $700-800$, making the sample size equal to 260 . To enhance response rate, $30 \%$ of 260 was added to the sample size totalling 338 in order to make room for uncertainties such as invalid or unreturned copies of questionnaire that could have hindered the ability of the researcher to gather valid data (Israel, 2013). Bowley's proportional allocation statistical technique was used in questionnaire distribution.

\section{The formula:}

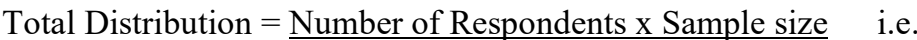
Total Target Population

Distribution allocation of Staff $=$ Total Distribution $\mathrm{x}$ Percentage Distribution/100

Where the Sample size $=338$

The study adopted multi-stage sampling technique due to its mixed nature. Multistage sampling is beneficial in terms of cost, speed and convenience of finding accuracy of a survey sample. Simple random and proportionate sampling methods were combined in stages for the study.

In stage one, the researcher adopted proportionate sampling method to determine the number of respondents to be investigated from the population as recommended by Bowley's proportional allocation statistical sample technique (Aldrich, 2008). The advantage of this sample technique lies in its simple ability to execute and produce a sample size that is representative of the size of a unit within population. After the proportional allocation between the study groups, the researcher in stage two used simple random sampling technique to administer the questionnaire. The justification for adopting this technique lies on the fact that the sample represents the target population. It eliminates bias and needs only a minimum knowledge of the study group of population in advance as representative of the population. It is free from errors in classification, suitable for data analysis which includes the use of inferential statistics. It is totally free from bias and prejudice. The method is simple to use as sampling error is easy to assess (Kouba, 2017).

The researcher adopted primary method of data collection using adapted questionnaire as earlier used by Frank and Obloj (2014) and Faheem and Mahmud (2015). This is necessary because data collection by primary source is central to any quantitative research as it provides fundamental connection between empirical observation and mathematical expression of quantitative relationships (Given, 2008). The objective of this method is to enable the researcher access unbiased result that can be generalized to a larger population. The research instrument was subjected to experts' opinion validity as recommended by Raza and Nawaz (2011). The instrument passed through face, content, and construct validity test to ascertain whether the question items really address the constructs. Principal component analysis method- a dimension reduction technique was employed for factor analysis test by the use of Kaiser-Meyer-Olkin and Bartlett tests of sphericity (Hadi, Abadullah \& Ijham, 2016). Also used was Average Variance Extract and composite reliability as recommended and utilised by Yusoff (2011) to determine construct validation. The KMO test valued higher than 5\% and Bartlett test of Sphericity result valued lesser than $5 \%$ showing that each variable actually measured what were intended. The result of the KMO and Bartlett test of Sphericity are stated in table 2.0, and all questionnaire items loaded high under each variables. Two research Assistants were specially trained to ensure accurate data collection and collation in the following areas: involvement of stakeholders in the process, addressing the anonymity issue, communicating the purpose, allowing the participants know that they are part of the sample, using follow-up reminders, considering a captive audience, communicating the timing of data flow and explaining how long it can take to complete the questionnaire.

Table 2. Results of the Factor Analysis Tests

\begin{tabular}{|l|l|c|c|c|c|}
\hline S/N & Constructs & Number of Items & KMO Test & Bartlett's Test & Sig \\
\hline 1. & Toxic Leadership & 7 & 0.555 & 407.044 .00 & 0.000 \\
\hline 2. & Organisational Silence & 7 & 0.603 & 318.336 .00 & 0.000 \\
\hline
\end{tabular}

\section{Source: Pilot Study, SPSS Output 2018}

Internal consistency test was conducted on the questionnaire using Cronbach's Alpha Reliability Analysis with the aid of Statistical Package for Science Solution (SPSS) version 21. A value of 0.704 to 0.775 showed that the research instrument is reliable. The constructs were greater than 0.7 (Cranach's @ $>0.70$ )

Table 3. Result of the Reliability Internal Test of Consistency

\begin{tabular}{|l|l|l|l|}
\hline S/N & Constructs & Number of Items & Cronbach's Alpha \\
\hline 1. & Toxic Leadership & 7 & 0.775 \\
\hline 2. & Organisational Silence & 7 & 0.704 \\
\hline
\end{tabular}

Source: Pilot Study, SPSS Output 2018

Descriptive and inferential methods of data analysis were adopted for the study. Descriptive presentation revealed percentage, mean and standard deviation of the of respondents' outcome as posited by Singh, Singh and Singh (2014). Inferential statistical analysis in a linear regression form analysed the effects of toxic leadership on organisational silence. The choice of linear regression for data analysis is depended on the strength that it allows independent variable to evaluate its predictive power over the dependent variables (Choudhary, Deswal \& Philip, 2013). This also helps to determine how much variance in the dependent variable (organisational silence) explains toxic leadership. 


\section{Data Analysis and Findings}

Tables 4 and 5 gave details of descriptive analysis of responses on Toxic Leadership and Organisational Silence. Using a six point Likert - like scale, the questionnaire had 7 items with a scale ranging from 1 to 6 . One (1) represented "very low" and six (6) represented "very high".

Table 4. Descriptive Statistics on Toxic Leadership

\begin{tabular}{|c|c|c|c|c|c|c|c|c|}
\hline Description & Level o & f Agree & ent in $s$ & of 1-6 & & & & \\
\hline Toxic Leadership & $\frac{1}{200}$ & 步 & 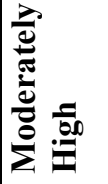 & 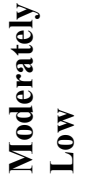 & בְ⿱ & $\frac{1}{3}$ & $\underset{\sum}{\stackrel{\Xi}{\tilde{d}}}$ & 异 \\
\hline Agressive behaviour & $0.5 \%$ & $29.8 \%$ & $47.5 \%$ & $15.8 \%$ & $4.4 \%$ & $1.9 \%$ & 4.010 & 0.910 \\
\hline Fear among employees & $0.3 \%$ & $30.1 \%$ & $51.4 \%$ & $9.6 \%$ & $5.7 \%$ & $3.0 \%$ & 4.010 & 0.954 \\
\hline Poor working conditions & $2.7 \%$ & $28.4 \%$ & $43.4 \%$ & $17.8 \%$ & $4.9 \%$ & $2.7 \%$ & 3.981 & 1.008 \\
\hline Policy violation & $13.4 \%$ & $31.4 \%$ & $23.2 \%$ & $21.3 \%$ & $8.5 \%$ & $2.2 \%$ & 4.134 & 1.259 \\
\hline $\begin{array}{l}\text { Hostile work } \\
\text { Environnent }\end{array}$ & $15.3 \%$ & $30.3 \%$ & $17.2 \%$ & $26.2 \%$ & $7.7 \%$ & $3.3 \%$ & 4.096 & 1.332 \\
\hline Devious politics & $11.5 \%$ & $17.8 \%$ & $18.6 \%$ & $40.7 \%$ & $8.2 \%$ & $3.3 \%$ & 3.740 & 1.266 \\
\hline $\begin{array}{l}\text { Poor leadership } \\
\text { Qualities }\end{array}$ & $7.4 \%$ & $10.1 \%$ & $10.4 \%$ & $40.7 \%$ & $26.0 \%$ & $5.2 \%$ & 3.216 & 1.608 \\
\hline Aggregate & & & & & & & 3.88 & 1.191 \\
\hline
\end{tabular}

\section{Source: Researcher's Field Survey, 2019}

According to the results in Table $4,0.5 \%$ of the respondents indicated that aggressive behaviour in their work place is very high, $29.8 \%$ indicated high, $47.5 \%$ moderately high, $15.8 \%$ moderately low, $4.4 \%$ low and $1.9 \%$ very low. On average, the respondents indicated that aggressive behaviour is moderately high with a mean of 4.010 and standard deviation of 0.910 . Results also indicated that $0.3 \%$ of the respondents responded very high to fear among employees, 30.1\% indicated high, 51.4\% moderately high, 9.6\% moderately low, and 5.7\% indicated low and 3\% very low. On average, the respondents indicated that fear among employees is moderately high with a mean of 4.010 and standard deviation of 0.954 . Also $2.7 \%$ of the respondents indicated that poor working conditions in their workplace is very high, $28.4 \%$ indicated high, $43.4 \%$ moderately high, 17.8 moderately low, $4.9 \%$ low and $2.7 \%$ very low. On average, the respondents indicated that poor working condition is moderately high with a mean of 3.981 and standard deviation of 1.008 . Results also indicated that $13.4 \%$ of the respondents responded very high to policy violation, $31.4 \%$ indicated high, $23.4 \%$ moderately high, $21.3 \%$ moderately low, $8.5 \%$ indicated low and $2.7 \%$ very low. On average, the respondents indicated that policy violation is moderately high with a mean of 4.134 and standard deviation of 1.259 .

Also $15.3 \%$ of the respondents indicated that hostility within the work environment is very high, $31.4 \%$ indicated high, $23.2 \%$ moderately high, $21.3 \%$ moderately low, $8.5 \%$ low and $2.2 \%$ very low. On average, the respondents indicated that hostile work environment is moderately high with a mean of 4.096 and standard deviation of 1.332 . Also $11.5 \%$ of the respondents indicated that devious politics in their workplace is very high, $17.8 \%$ indicated high, $18.6 \%$ moderately high, $40.7 \%$ moderately low, $8.2 \%$ low and $3.3 \%$ very low. On average, the respondents indicated that devious politics is moderately high with a mean of 3.740 and standard deviation of 1.266. Last item on the table shows that $7.4 \%$ of the respondents indicated that poor leadership qualities in their workplace is very high, $10.1 \%$ indicated high, $10.4 \%$ moderately high, $40.7 \%$ moderately low, $26 \%$ low and $5.2 \%$ very low. On average, the respondents indicated that poor leadership quality is moderately high with a mean of 3.216 and standard deviation of 1.608. The grand mean for toxic leadership is 3.88 with standard deviation of 1.191 , indicating that toxic leadership of the selected faith-based organisations in Ogun State is moderately high. 
Table 5. Descriptive Statistics on Organisational Silence

\begin{tabular}{|c|c|c|c|c|c|c|c|c|}
\hline Description & Level of & Agreeme & $t$ in scale & f 1-6 & & & & \\
\hline Organisational Silence & 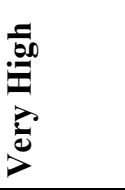 & 步 & 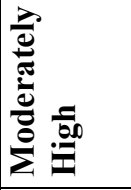 & 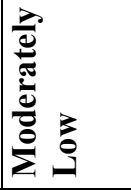 & ב⿱ & $\frac{3}{3}$ & 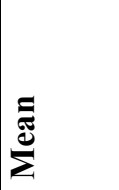 & 惫 \\
\hline Hesitate to speak & $1.1 \%$ & $27.9 \%$ & $49.7 \%$ & $17.2 \%$ & $2.7 \%$ & $1.4 \%$ & 4.030 & 0.853 \\
\hline $\begin{array}{l}\text { Hesitate to present a } \\
\text { reasonable argument }\end{array}$ & $0.8 \%$ & $28.7 \%$ & $51.6 \%$ & $12.0 \%$ & $5.2 \%$ & $1.6 \%$ & 4.030 & 0.892 \\
\hline Ignore adverse conditions & $2.7 \%$ & $26.0 \%$ & $42.6 \%$ & $23.0 \%$ & $3.8 \%$ & $1.9 \%$ & 3.951 & 0.961 \\
\hline $\begin{array}{l}\text { Hesitate to use discretion } \\
\text { in solving problems }\end{array}$ & $9.3 \%$ & $27.3 \%$ & $28.4 \%$ & $25.1 \%$ & $7.7 \%$ & $2.2 \%$ & 3.989 & 1.184 \\
\hline Keep thoughts to self & $11.2 \%$ & $25.7 \%$ & $24.6 \%$ & $31.7 \%$ & $4.9 \%$ & $1.9 \%$ & 4.008 & 1.181 \\
\hline $\begin{array}{l}\text { Scared of Superior's } \\
\text { reactions to suggestion or } \\
\text { action }\end{array}$ & $13.4 \%$ & $16.9 \%$ & $19.4 \%$ & $34.7 \%$ & $12.8 \%$ & $2.7 \%$ & 3.751 & 1.324 \\
\hline $\begin{array}{l}\text { Give consent to every } \\
\text { decision (no objection) }\end{array}$ & $12.3 \%$ & $6.6 \%$ & $12.8 \%$ & $39.1 \%$ & $27.0 \%$ & $2.2 \%$ & 3.314 & 1.327 \\
\hline Aggregate & & & & & & & 3.303 & 1.103 \\
\hline
\end{tabular}

\section{Source: Researcher's Field Survey, 2019}

Table 5 illustrated the respondents' opinion on Organisational silence. According to results in Table 5, 1.1\% respondents indicated very high as regards to hesitant to speak, $27.9 \%$ indicated high, $49.7 \%$ indicated moderately high, $17.2 \%$ indicated moderately low, $2.7 \%$ indicated low and $1.4 \%$ indicated very low. On average, the respondents indicated that being hesitant to speak is moderately high with a mean of 4.03 and a standard deviation of 0.853 . Result revealed that $0.8 \%$ respondents indicated very high as regards to hesitant to present a reasonable argument, $28.7 \%$ indicated high, $51.6 \%$ indicated moderately high, $12 \%$ indicated moderately low while $5.2 \%$ indicated low, and $1.6 \%$ indicated very low. On the average, the respondents indicated that hesitant to present a reasonable argument is moderately high with a mean of 4.03 and a standard deviation of 0.892 . As regards the ignoring adverse conditions, $2.7 \%$ respondents indicated very high, $26 \%$ indicated high, $42.6 \%$ indicated moderately high, $23 \%$ indicated moderately low, while $3.8 \%$ indicated low and $1.9 \%$ indicated very low. On the average, the respondents indicated that ignoring adverse conditions is moderately high with a mean of 3.95 and a standard deviation of 0.961 . With respect to hesitation to use discretion in solving problems, $9.3 \%$ respondents indicated very high, $27.3 \%$ indicated high, $28.4 \%$ indicated moderately high, $25.1 \%$ indicated moderately low while $7.7 \%$ indicated low and $2.2 \%$ indicated very low. On the average, the respondents indicated that hesitation to use discretion in solving problems is moderately high with a mean of 3.98 and a standard deviation of 1.184 .

Moreover, $11.2 \%$ of the respondents indicated very high to keep thoughts to self, $25.7 \%$ indicated high, $24.6 \%$ indicated moderately high, $31.7 \%$ indicated moderately low, while $4.9 \%$ indicated low, and $1.9 \%$ indicated very low. On the average, the respondents indicated that to keep thoughts to self is moderately high with a mean of 4.00 and a standard deviation of 1.181. Regarding scared of superior's reactions to suggestion, 13.4\% respondents indicated very high, $16.9 \%$ indicated high, $19.4 \%$ indicated moderately high, $34.1 \%$ indicated moderately low while $12.8 \%$ indicated low, and $2.7 \%$ indicated very low. On the average, the respondents indicated that scared of superior's reactions to suggestion is moderately high with a mean of 3.75 and a standard mean of 1.324. Lastly, $12.3 \%$ respondents indicated very high as regards to giving consent to every decision (no objection), $6.6 \%$ indicated high, $12.8 \%$ indicated moderately high, 39.1\% indicated moderately low, while 27.6\% indicated low, and $2.2 \%$ indicated very low. On the average, the respondents indicated that giving consent to every decision (no objection) is moderately high with a mean of 3.31 and a standard deviation of 1.327. The grand mean for organisational silence is 3.303 with standard deviation of 1.103 , indicating that organisational silence of the selected faith-based organisation is moderately high.

Subsequently, the analysis in table 4 and 5 presented positive perception of toxic leadership and organisational silence in the selected faith-based tertiary institutions in Ogun State, Nigeria, which means that toxic leadership and organisational silence is moderately high. Findings showed that the staff keep thoughts to themselves, hesitate to speak, and hesitate to present a reasonable argument. With this, it is affirmed that toxic leadership positively affect organisational silence in the selected faith-based organisations in Ogun State, Nigeria. These findings provided answer to the research question and enable the researcher to achieve the objective of the study.

Restatement of Hypothesis: Toxic leadership has no significant effect on organisational silence in the selected faith-based Organisation in Ogun State, Nigeria.

The researcher conducted linear regression analysis in testing the hypothesis with the dependent variable 
organisational silence, and independent variable toxic leadership. Data for toxic leadership and organisational silence were generated by summing responses of all items of the variables. To form the basis of testing the hypothesis, the test was done at significant level of $p<0.05$ such that when $p$-value was more than the significant level, the model is considered insignificant. The outline of the results is stated in Tables 6 .

Table 6. Regression Results on Effect of Toxic Leadership on Organisational Silence

\begin{tabular}{|c|c|c|c|c|}
\hline \multicolumn{5}{|c|}{ Model Summary } \\
\hline Model & $\mathbf{R}$ & R Square & Adjusted R Square & $\begin{array}{l}\text { Std. Error of the } \\
\text { Estimate }\end{array}$ \\
\hline 1 & $0.693^{\mathrm{a}}$ & 0.481 & 0.475 & 3.88070 \\
\hline
\end{tabular}

a. Predictor: (Constant), Toxic leadership

b) ANOVA

\begin{tabular}{|l|l|r|r|r|r|r|}
\multicolumn{2}{|l|}{ Model } & $\begin{array}{c}\text { Sum of } \\
\text { Squares }\end{array}$ & Df & Mean Square & F & Sig. \\
\hline \multirow{2}{*}{1} & Regression & 5035.25 & 4 & 1258.81 & 83.60 & $0.00^{\mathrm{b}}$ \\
\cline { 2 - 7 } & Residual & 5436.61 & 361 & & & \\
\cline { 2 - 8 } & Total & 10471.90 & 365 & & & \\
\end{tabular}

a. Dependent Variable: Organisational Silence

b. Predictors: (Constant), Toxic leadership

c) Coefficients

\begin{tabular}{|c|c|c|c|c|c|}
\hline Model & \multicolumn{2}{|c|}{$\begin{array}{c}\text { Unstandardized } \\
\text { Coefficients }\end{array}$} & $\begin{array}{c}\text { Standardized } \\
\text { Coefficients }\end{array}$ & \multirow{2}{*}{ T } & Sig. \\
\cline { 2 - 5 } & $\mathbf{B}$ & $\begin{array}{c}\text { Std. } \\
\text { Error }\end{array}$ & Beta & & \\
\hline & 8.80 & 1.22 & & 0.20 & 0.00 \\
\hline $\begin{array}{c}\text { Toxic } \\
\text { leadership }\end{array}$ & 0.30 & 0.10 & & 0.30 & 0.00 \\
\hline
\end{tabular}

a. Dependent Variable: Organisational Silence

\section{Source: Researcher's Field Results, 2019}

Table 6 presents the summary results of linear regression analysis of the effect of Toxic leadership on Organisational silence in the selected faith-based Organisation in Ogun State, Nigeria. Results showed that toxic leadership had significant effect on Organisational silence (Adj. $R^{2}=0.475 ; F(4,361)=83.60, p<0.05$ ). The overall Adj. $R^{2}$ value was 0.475 and it is significant at $\mathrm{p}$ value of 0.00 . This implies that toxic leadership explained $47.5 \%$ of the variations in Organisational silence in the selected faith-based Organisation in Ogun State Nigeria. There are other variables in the selected faith-based organisations which explained the remaining 52.5\%. Moreover, the analysis of variance from the model had the $\mathrm{F}$ value of 83.60 with $p$-value of 0.00 which is less than 0.05 . The finding showed that toxic leadership had statistical significant effect on Organisational silence, which means that there is significant linear relationship between the independent variable toxic leadership, and dependent variable Organisational silence.

Based on regression coefficients results in Table 6.0, the optimal model was found to be as follows:

$\mathrm{OS}=8.80+0.30 \mathrm{TL}$

Where:

OS = Organisational Silence

$\mathrm{TL}=$ Toxic Leadership

\section{Discussions}

From the regression equation established, taking Toxic Leadership is constant at zero, Organisational silence as a result of the independent factor would be 8.80. The result of the effect of Toxic Leadership manifestation showed that a unit increase in Toxic Leadership resulted in 0.30 units increase in Organisational Silence. Based on pvalues of the predictor, the null hypothesis which states that toxic-leadership has no significant effect on organisational silence in selected faith-based institution in Ogun State, Nigeria is hereby rejected. The objective of this study sought to determine the effect of Toxic Leadership on Organisational Silence in selected faith-based organisation in Ogun State, Nigeria. The study revealed that Toxic Leadership had positive and significant effect on Organisational Silence.

Earlier related studies also supported that there is significant effect of Toxic Leadership on Organisational Silence. This hypothesis is evidenced in the work of Frank and Oblog (2014) who maintained that a trade-off is required by organisation to choose between inclination for Toxic Leadership or increased staff productivity. Ermongkonchai (2010), Housman and Minor (2015) also found a significant effect of Toxic Leadership on Organisational Silence. 
Though, Pierce and Snyder (2008)'s investigations on the impact of workplace environment found toxic employees to be productive than other employees, Gino and Ariely (2012) and Frank and Obloj (2014) disagreed with the findings and maintained that toxic work environment has a negative effect on productivity. To buttress this view, Deter and Burris (2007) named three managerial factors that affect voicing and intention of employees to leave the workplace as change orientation, participation in decision making and access to organisational resources. The study revealed that employee's voice has significant effect on certain environmental factors, especially when the factors are high. This suggests that leadership attitude is critical to employees' voice behaviour. Pichora-Fuller et al. (2016) also identified with Deter and Burris (2007) that voice behaviour is positively related to employees' felt responsibility for constructive change. The finding is based on the fact that there is tendency of being constantly side-stepped when voicing out to offer certain suggestions on certain matters to superior. Hence, the study found significant effect between organisational silence and employees' performance. Similarly, Altuntas (2010) and Qureshi et al. (2015) in another study found toxic leadership having significant effect on emotional intelligence which could result to abnormal silence. It is obvious that the earlier findings corroborate the current finding in establishing that toxic leadership has significant effect on organisational silence. Further studies should be investigated to establish other factors $(52.5 \%)$ that affect Organisational silence in the selected faith-based Organisation in Ogun State, Nigeria.

\section{Conclusion and Recommendation}

The study investigated Toxic Leadership and Organisational Silence in selected faith-based organisations in Ogun State, Nigeria. The results produced statistical and empirical proofs on the effect of Toxic Leadership and Organisational Silence. The study showed that Toxic Leadership had positive and significant effects on organisational silence in the selected faith-based organisation in Ogun State, Nigeria. Therefore, the management and organisation expediently need to take every affordable option(s) to weaken the weight of organisational silence in the workplace by embarking on leadership with corporate ideology, cross fertilization of ideas, creativity, openness, and knowledge expansion as a culture that projects innovation, invention and integrity to curb the menace of Toxic Leadership that offers not much credibility and progression to a will-growing organisation. Suggested future works may examine the impact of some external environmental factors on organisational silence.

\section{References}

Acaray, A., \& Akturan, A. (2015). The relationship between organisational citizenship behaviour and organisation silence. Journal of Procedia-Social and Behavioural Sciences, 207, 472-482.

Adeoye, S. O. (2017). Workplace Discrimination and Talent Retention in Universities in Ogun State, Nigeria. M.Phil. dissertation, Department of Business Administration, Babcock University, Ogun State, Nigeria, 7081.

Akinyele, S. T. (2010). The influence of work environment on workers' productivity: A case of selected oil and gas industry in Lagos, Nigeria. African Journal of Business Management, 4(3), 299-307.

Aldrich, J. (2008). Bowley's theory of the representative method. Economics Division School of Social Sciences Journal, University of Southampton, Southampton. SO17 1BJ, UK.

Altuntas, C. (2010). A practical study on the concept and examples of mobbing. Journal of Yasar University, 5(18), 2995-3015.

Bagheri, G., Zarel, R., \& Aeen, M. N. (2012). Organisation silence: Basic concepts and its development factors. Journal of Ideal Types of Management, 1(1), 47-58.

Cetain, C., Karabay, M. E., Ozcan, D. E., \& Taskeran, E. (2013). The effect of personality traits on organisational silence: A research on service industry. $6^{\text {th }}$ International Conference on Service Management. Cyprus: Oxford Brooks University.

Choudhary, N., Deswal, R. K., \& Philip, P. J. (2013). Impact of Organisational justice on employees' workplace and personal outcomes: A study of Indian insurance sector. The IUP Journal of Organisational Behaviour, 7(4), 7-20.

Debios, S. (2016). 13 Creative ways to measure customer satisfaction using survey. Retrieved from http://surveyanyplace.com/questionnaire-pros-and cons/ on September, 2018.

Defranzo, S.E. (2012). Main benefits of survey research. Snap surveys. Retrieved from http://www.snapsurveys.com on June 10, 2018.

Deter, J. R., \& Burris, E. R. (2007). Leadership behaviour and employee voice: Is the door really open? The Academy of Management Journal, 50(4), 869-884.

Elci, M., Eridilek, K., Alpkan, L., \& Sener, I. (2014). The mediating role of mobbing on the relationship between organisational silence and turnover intention. Journal of Procedia-social and Behavioural Sciences, 150, 455 464.

Ellis, J.B., \& Dyne, L.V. (2009). Voice and silence as observers'reactions to defensive voice: Prediction based on communication competence theory. Emerald Group Publishing Limited, 37-61. 
Erdrencelebi, M., \& Sendogdu, A. A. (2016). Effects of mobbing and Organisational silence on employees' performance. The Macro theme Review: A multi-disciplinary Journal of Global Macro trends, 5(5), 101-116.

Ermongkonchai, P. (2010). Understanding reasons for employee unethical conduct in Thai Organisations: A qualitative inquiry. Contemporary Management Research Journal, 6(2), 125-140.

Faheem, M. A., \& Mahmud, N. (2015). The effects of Organisational justice on workplace deviance and job satisfaction of employees: Evidence from a public sector hospital in Pakistan. Mediterranean Journal of Social Sciences, 6(5), 342-352.

Frank, D. H., \& Oblog, T. (2014). Firm specific lumon capital, organisational incentive and gency cist: Evidence from retail banking. Strategic Management Journal, 35(9),1279- 1301.

Gilbert, J.A., Car- Ruffino, N., Ivancevich, J. M. \& Konopaske, R. (2012). Toxic versus cooperative behaviour at work: The role of Organisational culture and leadership in creating community centered organisations. International Journal of Leadership Studies, 7(1), 29-47.

Gino, F., \& Ariely, D. (2012). The dark side of creativity: Original thinkers can be more dishonest. Journal of Personality and Social Psychology, 102 (3), 445-455.

Given, L. M. (2008).Qualitative Research Methods. The SAGE Encyclopaedia of Los Angeles: SAGE Publications. ISBN 1-4129-4163-6.

Hadi, N. U., Abdulah, N., Ijham, S. (2016). An easy approach to exploratory factor analysis: Marketing perspective. Journal of Educational and Social Research, 6(10), 215-223.

Hollis, L. P. (2015). Bullying University? The Cost of workplace bullying and employee disengagement in American higher education, Sage Open Journal, 5(2), 21-58.

Housman, M., \& Minor, D. (2015) Toxic workers. Harvard Business School working paper16-57.

Huang, X., Van, V., \& Evert, V. (2005). Breaking the silence culture: Stimulation of participation and employee opinion withholding. Journal of Management and Organisation Review, 1(3), 1740-8776.

Hymowitz, C. (2007). Bosses have to learn how to confront troubled employees. The way street Journal, 23(7), 115.

Israel, G. D. (2013). Determining sample size. Agricultural education and communication department. University of Florida, IFAS Extension, PEOD6.

Karaca, H. (2013). An exploratory study on the impact of Organisational silence in hierarchical organisations: Turkish national police case. European Scientific Journal, 9(23), 38-50.

Karatepe, O. M., \& Shahriari, S. (2012). Job embeddedness as a moderator of the impact of Organisational justice on turnover intentions: A study in Iran. International Journal of Tourism Research, 16(1), 22-32.

Kaye, B., \& Jordan, E. (2014). What matters most? A White paper about organisational stay factors. Retrieved from httpp: //www.keepem.com on September 5, 2018.

Kilic, G., Tunc, T., Saracli, S., \& Kilic, I. (2013). The effect of organisational stress on organisational silence: An application in Five Star Hotel establishment. Journal of Business Research, 5(1), 7-32.

Kouba, K. (2017) Proportional representation, large district magnitude and closed lists. Prague, Hybernska: Centre for Ibero-American Studies of the Faculty of Arts, Charles University Press.

Krejcie, R.V., \& Morgan, D. W. (1970). Determining sample size for research activities. Journal of Educational and Psychological measurement, 30, 607-610.

Kumar, N. (2014). Role of perceived Organisational support and Organisational justice on employee turnover intentions: A literature review. International Journal of Management and Social Science Research Review, $1(5), 106-112$.

Kussy, M., \& Holloway, E. (2009). Toxic workplace: Managing toxic personalities and their systems of power. San Francisco, G. A., John Wiley \& Sons.

Lipmon- Blumen, J. (2016). Toxic leadership. Leading organisations: perspective for a new Era. $2^{\text {nd }}$ ed., $377-399$. Washington, DC: SAGE.

Malikeh, B., \& Zohre, R. (2012). Role of self-concept in organisations. European Journal of Economics, Finance and Administrative Sciences, 44(12), 1-7.

Malikeh, B., Hossein, B., \& Mahmood, N. M. (2012). Destructive role of employee silence in organisational success. International Journal of Academic Research in Business and Social Sciences, 2(11), 275-282.

Mehta, S., Maheshwari, G. C., \& Sharma, S. K. (2014). Role of leadership in leading successful change: An empirical study. Journal of contemporary management research, 8(2), 1-22.

Morrison, E. W. (2014). Employee Voice and Silence. Journal of the Annual Review of Organisational Psychology and Organisational Behaviour, 1(1), 173-197.

Morrison, W., \& Milliken, F. J. (2017). Organisation silence: A barrier to change and development in a pluralistic world. Journal of Academic of Management Review, 25(4), 706-725.

National Universities Commission Bulletin (May 14, 2018). List of approved universities in Nigeria. A publication of the Office of the Executive Secretary, 13(20), 17-27.

Oberholzer-Gee, F., \& Wulf, J. (2012). Incentives-based misconduct: Earning management from the bottom up: 
An analysis of managerial incentives below the CEO. HBS Working Paper, 12-56.

Ozdemir, L., \& Sarioglu-Ugur, S. (2013). The evaluation of employees' organisational voice and silence perceptions in terms of demographic characteristics: A study in public and private sector. Journal of Ataturk University Economics and Administrative Sciences, 27(1), 254-281.

Perlow, L., \& Williams, S. (2003). Is silence killing your company? Harvard Business Journal, 81(5), 52-128.

Pichora-Fuller, M. K., Kramer, S. E., \& Wingfield, A. (2016). Hearing impairment and cognitive energy: The framework for understanding effortful listening (FUEL). University of Nottingham. United Kingdom. China. Malaysia, 37(1), 1-24.

Pierce, L., \& Snyder, J. (2008). Ethical Spill overs in firms: Evidence from vehicle emissions testing. Management Science Journal, 54 (1) ,1891-1903.

Qureshi, I. M., Iftikhar, M., Janjua, J. S., \& Zaman, K. (2015). Empirical investigation of mobbing, stress and employees' behaviour at workplace: Quantitatively refining a qualitative model. Journal of Quality and Quantity, 49(1), 93-113.

Rastgar, A. A., \& Pourebralimi, N. (2013). A study of the relationship between organisational justice and turnover intentions: Evidence from Iran. International Journal of Organisational Behaviour and Human Resources Management, 1(2), 1-10.

Raza, M. A., Nawaz, M. M. (2011). Impact of job enlargement on employees' job satisfaction, motivation and Organisational commitment: Evidence from public sector of Pakistan. International Journal of Business and Social Science, 2(18), 20-31

Richard, N. (2003). Why do we remain silent in the face of unethical behaviour? The politics of ethics: Methods for acting, learning, and sometimes fighting with others in addressing ethics problems in organisational life. New York: Oxford University Press.

Sarnecki, A. (2015). Unemployment as a moderator of the Organisational justice turnover intentions relationship. Journal of Academy of Management Proceedings, 15(1), 1-15.

Singh, A. K., Singh, A., \& Singh, A. P. (2014). Personality traits and turnover intention among front level managerial personnel. Journal of the Indian Academy of Applied Psychology, 40(2), 228-236.

Souba, W., Way, D., Lucey, C., Sedmak, D., \& Notestinc, M. (2011). Elephant in academic medicine. Journal of the Association of American Medical College, 86(12), 1492-1499.

Spranger, A. (2008). Toxic Leadership and Organisational engagement, Journal of Virtues \& Leadership, 3(2), 112.

Tas, A., Boz-Semerci, A., \& Ergeneli, A. (2017). The mediating effect of silence within the Organisation in relationship between perceived mobbing and emotional burnout. Journal of Business Research, 9(1), 249270.

Taylor, F. (1974). Scientific management. New York: Harper and Row.

UNDP (2017). United Nations Development Programme Annual Report. Retrieved from htttp://www.ng.undp.org on April 16, 2018.

Van, D., L., Ang, S., Botero, I.C., (2003), Conceptualizing employee silence and employee voice as multidimensional constructs. Journal of Management Studies. 40(6), 1361-1369.

Van, D.L., Ang, S., \& Botero, I.C. (2008). Conceptualising employee silence and employee voice as multidimensional construct. Journal of management studies, 40(6), 1359-1392.

Van Hoof, H.B., Xu, S.T., Serrano, A., \& Torres, L. (2015). Abusive supervision - A form of workplace harassment: An exploratory study in the Ecuadorian hospitality industry. European Journal of Tourism, Hospitality and Recreation, 6(1), 103-121.

Vokola, M. (2014). Antecedent and consequences of organisation silence: An empirical investigation. Journal of Employees Relations, 27(5), 441-458.

Yusoff, M. S. (2011). A confirmatory factor analysis study on the medical student stressor questionnaire among Malaysian medical students. Education in Medicine Journal, 3 (1), 44-53.

Zimbardo, P. G. (2004). A Situationist perspective on the psychology of evil: Understanding how good people are transformed into perpetrators. The social-psychology of good and evil: Understanding our capacity for kindness and cruelty. New York: Guilford Press. 